\title{
HUBUNGAN SAFETY INSPECTION DAN PENGETAHUAN DENGAN UNSAFE ACTION DI DEPARTEMEN ROLLING MILL
}

\author{
RELATIONS BETWEEN SAFETY INSPECTION AND KNOWLEDGE \\ WITH UNSAFE ACTION IN ROLLING MILL DEPARTMENT
}

\author{
Intan Kristianti, Abdul Rohim Tualeka \\ Departemen Keselamatan dan Kesehatan Kerja \\ Fakultas Kesehatan Masyarakat Universitas Airlangga \\ E-mail: intan.kristianti31@gmail.com
}

\begin{abstract}
There are millions of workplace accidents in the world with the loss of hundreds of billions annually. One of the direct causes of accidents due to unsafe action. It stems from the lack of control by the management and the basic causes in the form of individual factors. This study is conducted to look at the factors correlated with unsafe action in the Department of Rolling Mill PT. X Sidoarjo. The research was conducted by observation using cross-sectional design and a quantitative approach. Questionnaires were administered to 70 respondents who were drawn using simple random sampling technique. The variables studied were safety inspection, knowledge, and unsafe action. Data was presented in the form of frequency distributions and cross-tabulations then statistically analyzed using Spearman correlation. The study was conducted using $\alpha$ of 0.05. The results showed that the respondents had a good knowledge, safety inspection in PT. X had been executed well, and had a lower category of unsafe action. There were a correlation between knowledge with unsafe action $(p=0.028 ; r=-0.262)$, and a correlation between safety inspection with unsafe action $(p=0.015 ; r=-0.288)$. It can be concluded that the higher knowledge and safety inspection, the unsafe action would be lower.
\end{abstract}

Keywords: knowledge, safety inspection, unsafe action

\begin{abstract}
ABSTRAK
Terdapat puluhan juta kecelakaan kerja di dunia dengan kerugian mencapai ratusan milyar setiap tahunnya. Salah satu penyebab langsung terjadinya kecelakaan dikarenakan unsafe action. Hal tersebut berawal dari lemahnya kontrol manajemen dan penyebab dasar yang berupa faktor individu. Penelitian ini dilakukan untuk melihat faktor yang berhubungan dengan unsafe action di departemen rolling mill PT. X Sidoarjo. Penelitian dilaksanakan secara observasi menggunakan rancangan cross sectional dan pendekatan kuantitatif. Kuesioner diberikan kepada 70 responden penelitian yang ditarik dari populasi pekerja menggunakan teknik simple random sampling. Variabel yang diteliti adalah safety inspection, pengetahuan, dan unsafe action. Data disajikan dalam bentuk distribusi frekuensi dan tabulasi silang kemudian dianalisis secara statistik menggunakan korelasi Spearman. Penelitian dilakukan dengan menggunakan $\alpha$ sebesar 0,05 . Hasil penelitian menunjukkan bahwa responden mempunyai pengetahuan yang baik dan menyatakan bahwa safety inspection di PT. X telah dilaksanakan dengan baik. Selain itu responden memiliki kategori unsafe action rendah. Terdapat hubungan antara pengetahuan dengan unsafe action $(\mathrm{p}=0,028 ; \mathrm{r}=-0,262)$ serta ada hubungan antara safety inspection dengan unsafe action ( $\mathrm{p}=0,015 ; \mathrm{r}=-0,288$ ). Simpulan penelitian ini bahwa semakin tinggi pengetahuan dan semakin baik penerapan safety inspection maka unsafe action akan semakin rendah.
\end{abstract}

Kata kunci: pengetahuan, safety inspection, unsafe action

\section{PENDAHULUAN}

Perkembangan dunia industri pada awal abad ke-21 ditandai dengan tingginya kejadian kecelakaan kerja yang terjadi. Berdasarkan data Hughes \& Ferrett (2013), terdapat 270 juta kecelakaan kerja yang terjadi di dunia dan perkiraan tersebut belum termasuk kecelakaan kerja yang tidak dilaporkan setiap tahunnya. Tingginya kecelakaan kerja yang terjadi menjadi salah satu dampak negatif akibat berkembangnya perindustrian dunia. Indonesia sebagai salah satu negara berkembang tidak luput dari dampak negatif akibat perkembangan industri yang terjadi. Suma'mur (2009) menyatakan bahwa 
kecelakaan kerja di Indonesia terjadi sekitar 100.000 kejadian dengan perkiraan korban meninggal dunia mencapai 2.000 jiwa setiap tahunnya.

Setiap kecelakaan kerja yang terjadi dapat memberikan kerugian bagi perusahaan. Kerugian dapat meliputi kerugian lingkungan, harta, benda, hingga kerugian jiwa. Aspek yang dapat memberikan kerugian lebih bagi perusahaan adalah kerugian yang melibatkan aspek manusia seperti cedera, sakit, kehilangan fungsi tubuh dan kerugian lainnya yang dapat menyebabkan keterbatasan atau bahkan kematian seseorang. Undang-Undang No. 13 Tahun 2003 telah menegaskan bahwa setiap tenaga kerja berhak mendapatkan perlindungan atas keselamatan dan kesehatan kerja. Tenaga kerja berhak untuk mendapat perlindungan dan terhindar dari hal yang dapat menyebabkan kerugian bagi dirinya. Salah satu cara untuk melindungi tenaga kerja dari kecelakaan kerja dan kerugian yang tidak diinginkan adalah dengan menerapkan keselamatan dan kesehatan kerja (K3) di perusahaan.

Keselamatan dan kesehatan kerja (K3) merupakan salah satu bentuk perlindungan bagi tenaga kerja serta merupakan hak dasar dari setiap tenaga kerja. Pada pasal 87 Undang-Undang No. 13 Tahun 2003 menyatakan bahwa setiap perusahaan wajib menerapkan sistem manajemen keselamatan dan kesehatan kerja (SMK3) dan terintegrasi dengan sistem manajemen perusahaan. Kewajiban penerapan SMK3 dilakukan untuk melindungi pekerja dari kecelakaan kerja. Semakin baik penerapan SMK3 di suatu perusahaan maka angka kecelakaan kerja akan semakin berkurang.

Terdapat banyak teori yang menjelaskan penyebab terjadinya kecelakaan kerja. Salah satu teori yang terkenal adalah teori Domino yang dikemukakan oleh Heinrich pada tahun 1931. Terdapat lima faktor dalam teori domino Heinrich, yaitu hereditas, kesalahan manusia, sikap dan kondisi tidak aman, kecelakaan kerja dan dampak kerugian. Menurut Safety Sign Indonesia (2015), hereditas mencakup latar belakang seseorang seperti pengetahuan yang kurang atau mencakup sifat seseorang. Faktor kesalahan atau kelalaian manusia meliputi motivasi yang rendah, stres, konflik, keahlian yang tidak sesuai dan sebagainya. Sikap dan kondisi tidak aman atau yang biasa dikenal dengan unsafe act dan unsafe condition merupakan kunci untuk mencegah kecelakaan kerja. Heinrich menyatakan bahwa penyebab terjadinya kecelakaan adalah tindakan tidak aman (unsafe action) dan kondisi tidak aman (unsafe condition). Menurut
Heinrich sebanyak $80-85 \%$ kecelakaan yang terjadi disebabkan oleh kelalaian atau kesalahan dari pekerja, sedangkan $15-20 \%$ sisanya terjadi karena kondisi yang tidak aman.

Selain teori domino, terdapat pula teori Loss Causation Model (Gambar 1.) yang merupakan modifikasi dari teori Heinrich. Teori tersebut dimodifikasi oleh Bird dan Germain pada tahun 1985 dengan menambahkan beberapa faktor penyebab terjadinya kecelakaan, yaitu faktor manajemen, penyebab dasar yang terdiri dari faktor individu dan faktor pekerjaan, serta penyebab langsung yang terdiri dari unsafe action dan unsafe condition. Menurut Bird \& Germain, faktor manajemen merupakan faktor utama terjadinya penyebab kecelakaan. Lemahnya manajemen dapat terjadi karena tiga alasan yaitu program tidak sesuai, standar tidak sesuai dan rendahnya kepatuhan terhadap standar pelaksanaan. Apabila faktor tersebut dapat dihilangkan atau diperbaiki, maka penyebab dasar dan penyebab langsung kecelakaan dapat diminimalisir.

Perbedaan teori domino Heinrich dan Bird \& Germain terdapat pada domino pertamanya. Pada teori domino Heinrich, domino pertama merupakan faktor lingkungan sosial seperti latar belakang seseorang, sedangkan domino pertama pada teori Bird \& Germain adalah faktor manajemen. Perbedaan tersebut dapat menjadi dasar pemilihan penggunaan teori yang sesuai untuk diterapkan di perusahaan. Hingga saat ini teori Bird dan Germain masih banyak digunakan untuk menentukan penyebab terjadinya kecelakaan kerja. Teori Bird dan Germain menyatakan bahwa tindakan tidak aman (unsafe action) dan kondisi tidak aman (unsafe condition) terjadi karena lemahnya kontrol manajemen. Stranks (2007) menyatakan bahwa lemahnya kontrol manajemen terjadi karena kegagalan dalam mempertahankan kepatuhan terhadap standar yang memadai, salah satunya adalah terhadap inspeksi yang telah direncanakan. Inspeksi dapat diartikan sebagai kegiatan pengawasan dan pemantauan yang dilaksanakan oleh perusahaan untuk menemukan dan melaporkan potensi bahaya sebelum terjadinya kecelakaan. Inspeksi juga merupakan salah satu metode yang dapat dilakukan untuk mengidentifikasi bahaya.

Menurut Hughes \& Ferrett (2013), identifikasi bahaya juga dapat dilakukan dengan audit. Terdapat perbedaan antara audit dan inspeksi K3. Inspeksi dilakukan untuk menemukan unsafe action dan unsafe condition yang terdapat di tempat kerja, 


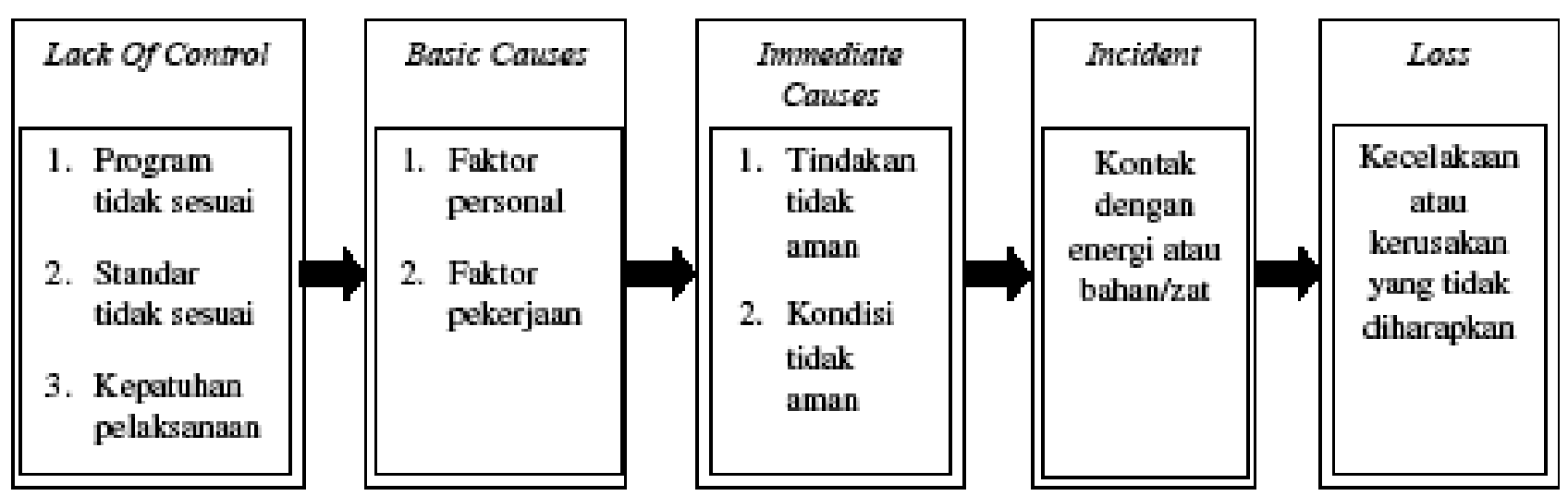

Gambar 1. Teori Loss Causation Model

sedangkan audit dilakukan untuk menguji secara sistematis terhadap seluruh kegiatan perusahaan untuk mengurangi kerugian. Selain itu, inspeksi K3 lebih berfokus pada kegiatan proyek sedangkan audit berfokus pada sistem. Menurut penelitian yang dilakukan oleh Rishadi (2008), pada dasarnya safety inspection dilakukan hanya untuk memastikan bahwa semua prosedur operasional yang dilakukan oleh pekerja telah dilaksanakan dengan benar tanpa mengumpulkan jumlah kesalahan yang ditemukan. Saat inspeksi apabila ditemukan kejanggalan pada tindakan pekerja, maka dapat diperbaiki saat itu juga sehingga tidak terjadi kecelakaan. Hasil penelitian yang dilakukan oleh Pratomo \& Widajati (2013) menyatakan bahwa apabila tingkat pemenuhan safety inspection di suatu perusahaan belum mencapai $100 \%$, maka masih terdapat kemungkinan atau risiko terdapat unsafe action dan unsafe condition yang dapat menyebabkan kecelakaan kerja.

Penyebab dasar terjadinya kecelakaan terdiri dari dua faktor, yaitu faktor individu dan faktor pekerjaan. Salah satu faktor pekerjaan yang dapat menyebabkan kecelakaan adalah karena pemeliharaan yang tidak memadai, perlengkapan atau peralatan kerja yang tidak memadai, dan kurangnya engineering. Faktor individu dapat terdiri dari karakteristik individu, pengetahuan, motivasi, kemampuan fisik serta mental. Menurut Pratama (2015), pengetahuan merupakan salah satu faktor yang berperan dalam menginterpretasikan stimulus yang diperoleh seseorang. Pekerja dapat mengidentifikasi bahaya apabila pengetahuan yang dimiliki baik sehingga dapat mencegah terjadinya kecelakaan. Pengetahuan merupakan hasil dari tahu dan hal tersebut terjadi setelah orang melakukan pengindraan terhadap objek tertentu.
ILCI menerangkan bahwa kurangnya pengetahuan yang dimaksud antara lain kurangnya latihan, orientasi yang tidak memadai, pelatihan yang tidak memadai dan pelatihan yang ada belum memadai. Pengetahuan dapat diperoleh melalui pengalaman maupun dari pembelajaran. Tindakan akan sesuai dengan pengetahuan seseorang jika seseorang tersebut menerima isyarat yang cukup kuat untuk memotivasi dirinya dalam bertindak sesuai dengan pengetahuannya (Oktavianti, 2014).

PT. X merupakan perusahaan yang bergerak di bidang industri baja dan menjadi salah satu produsen wire rod terbesar di Indonesia. PT. X didirikan pada tahun 1975 yang berlokasi di Sidoarjo. Sekitar 70\% hasil produksi dijual pada pasar domestik dan sekitar $30 \%$ untuk pasar ekspor di kawasan regional asia pasifik. Proses produksi yang dilakukan di PT. X banyak menggunakan teknologi canggih dan bahan berbahaya yang dapat membahayakan pekerja. Berdasarkan data kecelakaan yang didapat di PT. $\mathrm{X}$ selama 5 tahun terakhir terdapat 82 kecelakaan dan 13 kejadian near miss yang disebabkan oleh unsafe action yang dilakukan oleh pekerjanya. Telah dijelaskan sebelumnya bahwa penyebab langsung terjadinya kecelakaan adalah $85 \%$ akibat faktor unsafe action dan 15\% sisanya terjadi karena unsafe condition. Unsafe action terjadi karena faktor manusia dan lemahnya kontrol manajemen. Maka dari itu peneliti ingin melakukan analisis hubungan antara safety inspection dan pengetahuan pekerja dengan unsafe action. Setelah mengetahui hubungan keduanya, maka dapat dilakukan upaya pencegahan dan pengendalian untuk mengurangi kejadian kecelakaan dan near miss yang terjadi di PT. X khususnya Departemen Rolling Mill. 


\section{METODE}

Jenis penelitian yang digunakan oleh peneliti adalah penelitian observasional dengan menggunakan pendekatan cross-sectional study. Hal tersebut dikarenakan penelitian ini tidak memberikan eksperimen atau perlakuan kepada subjek penelitian serta dilakukan pada satu kurun waktu. Menurut segi pengolahan dan analisis data penelitian ini tergolong dalam penelitian analitik, karena akan melihat dan menjelaskan faktor yang berhubungan dengan unsafe action pekerja. Jika ditinjau dari segi tempat pelaksanaan, maka penelitian ini termasuk jenis penelitian lapangan. Lokasi yang digunakan dalam pengumpulan data penelitian adalah PT. X yang terdapat di daerah Sidoarjo.

Populasi penelitian ini adalah seluruh pekerja Departemen Rolling Mill yang berjumlah 84 orang. Peneliti melakukan pengambilan sampel untuk mengeneralisasikan populasi serta menghindari kemungkinan dropout responden. Terdapat kriteria inklusi dalam pengambilan sampel tersebut yaitu pekerja merupakan pekerja tetap di Departemen Rolling Mill. Penentuan kriteria inklusi dilakukan karena terdapat pekerja yang berstatus kontrak dan pekerja dari departemen lain yang ikut membantu pekerjaan di Departemen Rolling Mill. Pengambilan sampel dilakukan dengan menggunakan teknik simple random sampling dengan derajat penyimpangan sebesar $5 \%$ dan proporsi sebesar $50 \%$, sehingga didapat jumlah sampel sebesar 70 responden.

Variabel yang digunakan dalam penelitian ini yaitu safety inspection, pengetahuan, dan unsafe action. Variabel tersebut dikelompokkan menjadi dua variabel, yaitu variabel terikat dan variabel bebas. Variabel terikat pada penelitian ini adalah unsafe action, sedangkan variabel bebas terdiri dari safety inspection, dan pengetahuan. Data primer mengenai variabel tersebut akan diambil dengan kuesioner, sedangkan untuk data sekunder didapatkan melalui data yang telah ada di PT. X.

Pengambilan data dilakukan ketika jam istirahat responden. Peneliti terlebih dulu membacakan penjelasan sebelum persetujuan kepada responden. Selanjutnya jika responden bersedia, maka responden akan diminta untuk mengisi lembar informed consent. Setelah itu responden akan diberikan lembar kuesioner serta dipandu dalam pengisiannya. Setelah proses pengambilan data selanjutnya akan dilakukan analisis data. Teknik analisis data dilakukan dengan analisis univariat dan analisis bivariat.
Pada analisis univariat dilakukan dengan cara menyajikan data dalam bentuk distribusi frekuensi dan persentase dari tiap variabel, sedangkan analisis bivariat dilakukan dengan menggunakan uji korelasi Spearman dengan $\alpha=5 \%$ untuk melihat hubungan. Kuat hubungan dapat dilihat melalui koefisien korelasi yang bernilai -1 sampai 1. Jika mendekati angka satu, maka korelasi akan semakin kuat, sedangkan jika mendekati angkat nol, maka korelasinya akan melemah.

Pengumpulan data mengenai safety inspection dilakukan dengan menanyakan persepsi responden mengenai penerapannya di Departemen Rolling Mill melalui 10 butir pertanyaan. Pemberian skor untuk pertanyaan safety inspection dilakukan dengan menggunakan skala likert dengan skor 4 sangat sering, 3 sering, 2 kadang-kadang, dan 1 tidak pernah. Jawaban responden akan dijumlah untuk mendapatkan total skor. Jika skor $>75 \%$ mendapat kategori baik, skor 50-75\% kategori cukup, dan skor $<50 \%$ mendapat kategori kurang.

Pengukuran pengetahuan dilakukan dengan menggunakan 7 pertanyaan mengenai $\mathrm{K} 3$ dan unsafe action. Jika responden menjawab pertanyaan dengan benar maka akan mendapat skor 1, sedangkan apabila memilih jawaban yang salah responden tidak akan mendapatkan skor. Setelah menjawab semua pertanyaan pengetahuan, tiap skor akan dijumlah untuk mendapatkan total skor. Apabila skor $>75 \%$ berarti tingkat pengetahuan responden baik, $56-75 \%$ berarti cukup, sedangkan $<56 \%$ berarti tingkat pengetahuan kurang (Arikunto, 2006).

Data unsafe action didapatkan berdasarkan 16 tindakan tidak aman menurut Wicaksono (2014). Kuesioner mengenai unsafe action disajikan dengan opsi jawaban Ya atau Tidak dan responden memilih berdasarkan tindakan yang dilakukannya dalam satu bulan terakhir. Jika responden memilih jawaban Ya, maka akan diberi skor 1 . Responden yang memilih jawaban Tidak, akan diberi skor 0. Jika skor yang dihasilkan $>75 \%$ maka akan dikategorikan selalu melakukan unsafe action, 50-75\% sering melakukan, dan $<50 \%$ kadang-kadang melakukan unsafe action.

\section{HASIL}

\section{Safety Inspection}

Penerapan safety inspection di Departemen Rolling Mill dikategorikan menjadi tiga yaitu baik, cukup, dan kurang. Safety inspection dapat 
Tabel 1. Distribusi Safety Inspection di Departemen Rolling Mill

\begin{tabular}{lcc}
\hline Safety Inspection & Frekuensi & Persentase (\%) \\
\hline Baik & 36 & 51,4 \\
Cukup & 28 & 40,0 \\
Kurang & 6 & 8,6 \\
\hline Total & 70 & 100,0 \\
\hline
\end{tabular}

Tabel 2. Distribusi Pengetahuan Pekerja di Departemen Rolling Mill

\begin{tabular}{lcc}
\hline Pengetahuan & Frekuensi & Persentase (\%) \\
\hline Baik & 53 & 75,7 \\
Cukup & 14 & 20,0 \\
Kurang & 3 & 4,3 \\
\hline Total & 70 & 100,0 \\
\hline
\end{tabular}

dikatakan baik apabila skor $\geq 75 \%$, cukup apabila skor $50-75 \%$, dan kurang apabila skor $<50 \%$.

Berdasarkan Tabel 1 diketahui bahwa sebagian besar responden menjawab bahwa kegiatan safety inspection telah dilaksanakan dengan baik $(51,4 \%)$, sedangkan sebanyak $40 \%$ responden menyatakan bahwa penerapannya telah cukup, dan $8,6 \%$ sisanya menyatakan bahwa penerapan safety inspection termasuk kategori kurang. Tingginya persepsi pekerja mengenai pelaksanaan safety inspection berarti bahwa pelaksanaan inspeksi di Departemen Rolling Mill telah dilaksanakan dengan baik.

\section{Pengetahuan}

Pengetahuan pekerja yang diteliti ialah pengetahuan mengenai $\mathrm{K} 3$ dan unsafe action. Pengetahuan dikategorikan menjadi baik, cukup, dan kurang. Pengetahuan dikategorikan baik apabila jawaban benar $>75 \%$, cukup apabila jawaban benar $56-75 \%$, dan kurang apabila jawaban benar $<56 \%$. Berdasarkan hasil distribusi pada Tabel 2, diketahui sebanyak $75,7 \%$ responden memiliki pengetahuan yang baik mengenai keselamatan kerja, khususnya mengenai tindakan tidak aman. Sekitar $20 \%$ responden memiliki tingkat pengetahuan cukup dan $4,3 \%$ berpengetahuan kurang.

\section{Unsafe Action}

Hasil kuesioner menunjukkan bahwa jenis unsafe action yang paling banyak dilakukan oleh responden dalam satu bulan terakhir adalah ketidakrapian dalam penataan barang maupun alat kerja (housekeeping yang buruk), tidak diperingatkan oleh rekan kerja apabila melakukan kesalahan, dan mengoperasikan alat kerja yang bukan tanggung jawabnya. Sedangkan jenis unsafe action yang paling jarang dilakukan oleh responden ialah berada dalam keadaan mabuk atau mengantuk saat bekerja, tidak menggunakan APD ketika bekerja, dan menggunakan peralatan kerja yang tidak sesuai dengan pekerjaannya.

Kategori unsafe action dibagi menjadi tiga yaitu kadang-kadang atau jarang melakukan unsafe action, sering melakukan, dan selalu melakukan unsafe action. Berdasarkan hasil penelitian pada Tabel 3 diketahui bahwa dalam satu bulan terakhir sebagian besar responden kadang-kadang melakukan unsafe action $(87,1 \%)$. Hanya $11,4 \%$ responden yang sering dan $1,4 \%$ responden yang selalu melakukan unsafe action dalam satu bulan terakhir.

\section{Hubungan Safety Inspection dengan Unsafe Action}

Hasil penelitian pada Tabel 4 menyatakan bahwa sebanyak 55,7\% responden yang jarang melakukan unsafe action adalah responden yang mempunyai persepsi baik tentang safety inspection. 39,3\% diantaranya mengatakan bahwa safety inspection yang dilaksanakan sudah cukup sesuai dan 4,9\% jarang melakukan unsafe action menyatakan bahwa safety inspection yang dilakukan di area kerjanya kurang baik. Hal tersebut menunjukkan bahwa semakin baik pelaksanaan safety inspection di tempat kerja maka unsafe action yang dilakukan juga semakin jarang.

Analisis menggunakan uji korelasi Spearman dengan nilai $\alpha$ sebesar $5 \%$ menunjukkan nilai yang signifikan yaitu nilai $p$-value $(0,015)<\alpha(0,05)$. Hal tersebut menunjukkan bahwa terdapat hubungan antara safety inspection dengan unsafe action dengan besar koefisien korelasi sebesar -0,288 yang menyatakan bahwa terdapat hubungan yang cukup antar keduanya. Nilai korelasi minus (-) menunjukkan bahwa hubungan bersifat berlawanan arah, sehingga dapat disimpulkan bahwa semakin baik safety inspection maka akan semakin rendah tingkat unsafe action yang dilakukan, begitu pun sebaliknya.

\section{Hubungan Pengetahuan dengan Unsafe Action}

Tabel 5 menunjukkan mayoritas responden yang kadang-kadang melakukan unsafe action 
Tabel 3. Distribusi Unsafe Action di Departemen Rolling Mill

\begin{tabular}{lcc}
\hline Unsafe Action & Frekuensi & Persentase (\%) \\
\hline Selalu & 1 & 1,4 \\
Sering & 8 & 11,4 \\
Kadang-kadang & 61 & 87,1 \\
\hline Total & 70 & 100,0 \\
\hline
\end{tabular}

memiliki pengetahuan yang baik. Responden yang sering melakukan unsafe action, 50\% diantaranya memiliki pengetahuan yang cukup dan 50\% sisanya memiliki pengetahuan yang baik. Hasil analisis uji statistik yang dilakukan dengan uji korelasi Spearman didapatkan nilai $p$-value sebesar 0,028 dan nilai $p$-value $<\alpha(0,05)$ yang berarti bahwa Ho ditolak atau terdapat hubungan antara pengetahuan dengan unsafe action yang dilakukan oleh pekerja di Departemen Rolling Mill. Nilai koefisien korelasi yang didapat sebesar -0,262 yang berarti bahwa terdapat kuat hubungan yang cukup antara pengetahuan dengan unsafe action. Nilai korelasi negative (-) menunjukkan bahwa hubungan bersifat berlawanan arah, yang berarti semakin baik pengetahuan responden maka semakin rendah kategori unsafe action yang dilakukan, begitu juga sebaliknya semakin kurang pengetahuan maka akan semakin tinggi kategori atau semakin sering unsafe action yang dilakukan.

\section{PEMBAHASAN Hubungan Safety Inspection dengan Unsafe
Action}

Tabel 2 menunjukkan mayoritas responden menyatakan penerapan safety inspection telah dilaksanakan dengan baik. Pekerja menjelaskan bahwa safety inspection di Departemen Rolling Mill dilakukan secara teratur sesuai jadwal dan petugas inspeksi sering memeriksa kelengkapan APD dan menegur apabila pekerja melakukan kelalaian. Suardi (2007) menyatakan bahwa kecelakaan dapat dicegah dengan memperbaiki faktor utama terjadinya kecelakaan yaitu faktor manajemen keselamatan dan kesehatan kerja. Salah satu contoh faktor manajemen keselamatan dan kesehatan kerja menurut Stranks (2007) adalah program safety inspection. Menurut Tarwaka (2014), program safety inspection merupakan suatu program pencegahan yang sangat penting dilakukan untuk menjamin agar lingkungan kerja selalu aman, sehat, dan selamat.

PT. X telah melaksanakan program safety inspection dengan baik ditandai dengan tingginya persepsi pekerja terhadap pelaksanaan safety

Tabel 4. Hubungan Safety Inspection dengan Unsafe Action di Departemen Rolling Mill

\begin{tabular}{|c|c|c|c|c|c|c|c|c|c|c|}
\hline \multirow{3}{*}{$\begin{array}{c}\text { Safety } \\
\text { Inspection }\end{array}$} & \multicolumn{6}{|c|}{ Unsafe Action } & \multirow{2}{*}{\multicolumn{2}{|c|}{ Total }} & \multirow{3}{*}{ p-value } & \multirow{3}{*}{$\begin{array}{l}\text { Koefisien } \\
\text { Korelasi }\end{array}$} \\
\hline & \multicolumn{2}{|c|}{ Selalu } & \multicolumn{2}{|c|}{ Sering } & \multicolumn{2}{|c|}{ Kadang-kadang } & & & & \\
\hline & $\mathbf{n}$ & $\%$ & $\mathbf{n}$ & $\%$ & $\mathrm{n}$ & $\%$ & $\mathbf{N}$ & $\%$ & & \\
\hline Baik & 0 & 0,0 & 2 & 25,0 & 34 & 55,7 & 36 & 51,4 & \multirow{4}{*}{0,015} & \multirow{4}{*}{$-0,288$} \\
\hline Cukup & 1 & 100,0 & 3 & 37,5 & 24 & 39,3 & 28 & 40,0 & & \\
\hline Kurang & 0 & 0,0 & 3 & 37,5 & 3 & 4,9 & 6 & 8,6 & & \\
\hline Total & 1 & 100,0 & 8 & 100,0 & 61 & 100,0 & 70 & 100,0 & & \\
\hline
\end{tabular}

Tabel 5. Hubungan Pengetahuan dengan Unsafe Action di Departemen Rolling Mill

\begin{tabular}{|c|c|c|c|c|c|c|c|c|c|c|}
\hline \multirow{3}{*}{ Pengetahuan } & \multicolumn{6}{|c|}{ Unsafe Action } & \multirow{2}{*}{\multicolumn{2}{|c|}{ Total }} & \multirow{3}{*}{ p-value } & \multirow{3}{*}{$\begin{array}{c}\text { Koefisien } \\
\text { Korelasi }\end{array}$} \\
\hline & \multicolumn{2}{|c|}{ Selalu } & \multicolumn{2}{|c|}{ Sering } & \multicolumn{2}{|c|}{$\begin{array}{c}\text { Kadang- } \\
\text { kadang }\end{array}$} & & & & \\
\hline & $\mathbf{n}$ & $\%$ & n & $\%$ & $\mathrm{n}$ & $\%$ & $\mathbf{N}$ & $\%$ & & \\
\hline Baik & 0 & 0,0 & 4 & 50,0 & 49 & 80,3 & 53 & 75,7 & \multirow{4}{*}{0,028} & \multirow{4}{*}{$-0,262$} \\
\hline Cukup & 1 & 100,0 & 4 & 50,0 & 9 & 14,8 & 14 & 20,0 & & \\
\hline Kurang & 0 & 0,0 & 0 & 0,0 & 3 & 4,9 & 3 & 4,3 & & \\
\hline Total & 1 & 100,0 & 8 & 100,0 & 61 & 100,0 & 70 & 100,0 & & \\
\hline
\end{tabular}


inspection di tempat kerja. PT. X melakukan safety inspection secara formal dan informal. Inspeksi secara formal dilakukan setiap satu bulan sekali sedangkan secara informal dilakukan setiap hari. Hal tersebut sesuai dengan teori Hughess \& Ferrett (2013) bahwa inspeksi dapat dilakukan 1 sampai 2 bulan sekali dan dapat dilakukan setiap hari jika risiko di tempat kerja sangat berbahaya. Menurut Tarwaka (2014), pelaksanaan safety inspection terdiri dari tahap persiapan, tahap pelaksanaan, tahap pengembangan upaya perbaikan, dan tahap tindakan korektif. PT. X telah melaksanakan safety inspection sesuai dengan tahapan tersebut.

Sebelum melakukan inspeksi, departemen SHE akan menentukan area yang akan di inspeksi dan inspektor yang telah ditunjuk akan melakukan persiapan seperti membawa checklist, membawa alat tulis, mengenakan alat pelindung diri, dan membawa dokumentasi berupa kamera.

Pada tahap pelaksanaan inspeksi, inspektor menelusuri area kerja yang ditentukan dan berpedoman pada checklist. Inspeksi dilakukan dengan cara observasi terhadap kondisi lingkungan kerja, peralatan dan tindakan pekerja serta diperiksa kesesuaiannya dengan standard yang terdapat di dalam checklist inspeksi. Apabila ditemukan ketidaksesuaian di lapangan maka dicatat temuan tersebut pada formulir laporan inspeksi kerja yang ada. Apabila inspeksi sudah selesai maka dilakukan pertemuan dengan penanggung jawab area yang diinspeksi untuk mendapatkan klarifikasi terhadap hasil temuan di lapangan. Pada pertemuan itu juga disampaikan rekomendasi bentuk tindakan perbaikan yang akan dilakukan, penanggung jawab tindakan serta target waktu penyelesaiannya.

Setelah itu pada tahap pengembangan upaya perbaikan akan dilakukan tindak lanjut sementara sebelum mengambil tindakan korektif permanen. Contohnya ketika inspektor melihat pekerja tidak mengenakan APD, maka pekerja tersebut akan langsung ditegur oleh inspektor. barang jika berserakan dapat menyebabkan kecelakaan, maka petugas inspeksi akan langsung merapikan barang tersebut dibantu oleh penanggung jawab area.

Tahap keempat berupa pengambilan tindakan korektif dilakukan jika terdapat temuan yang tidak dapat langsung diperbaiki dengan cara memasang tag yang menjelaskan kondisi peralatan tersebut rusak dan tidak layak pakai serta segera melakukan perbaikan atau penggantian. Lalu inspektor akan melaporkan temuan tersebut melalui formulir laporan inspeksi beserta rekomendasi tindakan perbaikannya kepada tim P2K3 atau kepala departemen terkait. Selanjutnya tindakan perbaikan yang diusulkan oleh tim inspeksi akan dipantau dan dikoordinasikan dengan departemen terkait. Apabila tindakan perbaikan memerlukan kewenangan dari pihak manajemen, maka usulan tindakan perbaikan tersebut dibahas dalam rapat $\mathrm{P} 2 \mathrm{~K} 3$ atau rapat khusus bila diperlukan.

Safety inspection yang dimaksud dalam penelitian ini adalah persepsi pekerja tentang safety inspection yang dilakukan oleh departemen SHE dalam melakukan pengawasan dan pemantauan untuk mengontrol keadaan lapangan dan aktivitas pekerja untuk menghindari unsafe action dan unsafe condition yang dapat menyebabkan kecelakaan. Penerapan safety inspection di PT. X telah dilaksanakan dengan baik, hal tersebut dapat dilihat dari tindakan pekerja yang jarang melakukan unsafe action. Petugas SHE atau inspektor akan menegur apabila menemukan pekerja yang melakukan unsafe action dan tidak mengikuti SOP yang berlaku. Pada saat pelaksanaan inspeksi, inspektor lebih sering menegur pekerja yang tidak menggunakan APD daripada pekerja yang sembarangan meletakkan barangnya. Hal tersebut membuat pekerja lebih jarang melakukan tindakan tidak aman seperti tidak menggunakan APD. Inspektor lebih fokus pada pekerja daripada lingkungan sekitarnya sehingga housekeeping tidak terlalu diperhatikan. Tuntutan deadline dalam penyelesaian proyek membuat pekerja terburu-buru dalam melakukan pekerjaannya, sehingga pekerja tidak begitu memperhatikan tata letak barang dan alat kerjanya. Peletakan barang maupun alat kerja yang sembarangan dapat membuat terjadinya near miss hingga kecelakaan. Salah satu contoh jenis kecelakaan yang dapat terjadi akibat housekeeping yang buruk adalah tersandung oleh alat kerja.

Bird \& Germain memodifikasi teori domino Heinrich dengan menambahkan faktor manajemen sebagai penyebab utama terjadinya kecelakaan. Faktor manajemen dari teori Bird \& Germain dapat diartikan sebagai lemahnya kontrol manajemen terhadap peraturan dan kebijakan yang mengatur tentang suatu pekerjaan. Faktor manajemen dalam penelitian ini adalah safety inspection. Safety inspection merupakan program $\mathrm{K} 3$ yang diartikan sebagai kegiatan pengawasan dan pemantauan yang dilaksanakan oleh perusahaan untuk menemukan dan melaporkan potensi bahaya sebelum terjadinya kecelakaan. Hasil observasi diperoleh bahwa pihak perusahaan telah memiliki peraturan terkait 
pelaksanaan safety inspection yang terdapat dalam prosedur departemen SHE PT. X.

Ketidakrapian dalam penataan barang dan alat kerja menjadi salah satu tindakan tidak aman yang sering dilakukan oleh pekerja. Penataan barang atau housekeeping yang baik dapat memudahkan pekerjaan sekaligus mengurangi risiko terjadinya kecelakaan. Salah satu cara PT. X untuk mengendalikan housekeeping adalah dengan menerapkan Ringkas, Rapi, Resik, Rawat, dan Rajin (5R) di perusahaan. Namun ternyata masih terdapat beberapa pekerja yang masih tidak rapi dalam penataan barang dan alat kerjanya.

Jenis unsafe action kedua yang banyak dilakukan adalah tidak diperingatkan oleh rekan kerja apabila melakukan kesalahan. Hal tersebut berarti bahwa pekerja gagal dalam mengingatkan rekan kerjanya dan membiarkannya melakukan kesalahan. Tindakan seperti ini dapat menyebabkan kecelakaan, karena pekerja tidak mengetahui bahwa ia telah berbuat salah dan sewaktu-waktu dapat mengulangi kesalahan yang sama sehingga memberi celah untuk terjadinya kecelakaan. Apabila pekerja melihat rekan kerjanya melakukan kesalahan, maka ia perlu diingatkan. Hal tersebut dilakukan karena pengawas atau petugas K3 bisa saja luput dalam mengawasi pekerja, sehingga peran pekerja dalam menegur dan mengingatkan kesalahan rekan kerja sangat dibutuhkan.

Tindakan tidak aman lainnya yang banyak dilakukan adalah mengoperasikan alat kerja yang bukan tanggung jawabnya. Tindakan tersebut dilakukan oleh pekerja tanpa seizin pengawas yang bertugas. Menggunakan peralatan yang bukan tanggung jawabnya merupakan tindakan yang tidak diperbolehkan karena dapat menyebabkan terjadinya kecelakaan. Perusahaan telah membuat peraturan mengenai hal tersebut, bahwa hanya pekerja yang telah mempunyai Surat Ijin Operasi (SIO) saja yang dapat mengoperasikan peralatan kerja. Sehingga hanya petugas yang berwenang yang dapat mengoperasikan peralatan kerja yang sesuai dengan SIO dan tanggung jawabnya. Namun masih terdapat beberapa pekerja yang menyatakan telah mengoperasikan peralatan kerja yang bukan tanggung jawabnya.

Salah satu jenis unsafe action yang jarang dilakukan adalah mengantuk atau mabuk. Pekerja PT. X menyatakan bahwa di perusahaan tersebut terdapat peraturan yang melarang pemakaian minuman keras ketika sedang bekerja, sehingga tidak terdapat pekerja yang mabuk. Namun terdapat beberapa pekerja yang mengantuk ketika melakukan pekerjaannya. Hal tersebut dapat membahayakan dirinya sendiri karena dapat menurunkan kewaspadaan diri. Selain itu jenis tindakan tidak aman lainnya yang jarang dilakukan ialah tidak menggunakan alat pelindung diri ketika bekerja. Hampir semua pekerja di PT. X khususnya yang bekerja di departemen RML menggunakan APD yang sesuai. Salah satu contoh penggunaan APD yang wajib ketika berada di plant area perusahaan adalah dengan menggunakan safety shoes dan helm. APD seperti earplug, kacamata, dan masker hanya dikenakan di area tertentu dengan pekerjaan tertentu saja.

Teori loss causation model merupakan teori yang menyatakan bahwa unsafe action adalah salah satu penyebab langsung terjadinya kecelakaan. Unsafe action jika dapat diminimalisir atau dihilangkan, maka kejadian kecelakaan juga akan semakin berkurang. Berdasarkan Tabel 4, mayoritas responden melakukan unsafe action dengan kategori jarang atau kadang-kadang dilakukan. Tidak menutup kemungkinan bahwa tindakan tidak aman tersebut dapat menyebabkan kecelakaan kerja sewaktu-waktu walaupun jarang dilakukan.

Berdasarkan hasil analisis pada Tabel 4 diketahui bahwa terdapat hubungan yang bermakna secara statistik antara safety inspection dengan unsafe action. Hubungan tersebut memiliki korelasi negatif yang berarti semakin baik safety inspection maka semakin rendah unsafe action yang dilakukan oleh pekerja begitu juga sebaliknya. Hal tersebut sejalan dengan penelitian Permatasari (2015) yang menyatakan bahwa terdapat hubungan antara pengawasan dengan tindakan tidak aman. Penelitian tersebut menyatakan bahwa semakin baik persepsi responden terhadap pengawasan, maka semakin rendah tindakan tidak aman yang dilakukan oleh responden. Suma'mur (2009) juga menyatakan perlu dilakukannya safety inspection sebagai bentuk pengawasan dan pemantauan untuk penerapan $\mathrm{K} 3 \mathrm{di}$ perusahaan.

\section{Hubungan Pengetahuan dengan Unsafe Action}

Pengetahuan yang dimaksud dalam penelitian ini adalah pengetahuan mengenai $\mathrm{K} 3$ dan unsafe action yang dikategorikan menjadi tiga yaitu baik, cukup, dan kurang. Berdasarkan Tabel 1, mayoritas tingkat pengetahuan yang dimiliki oleh responden adalah baik. Hal tersebut menunjukkan bahwa responden telah mengerti mengenai $\mathrm{K} 3$ dan unsafe action. Pengetahuan bisa didapat dari berbagai sumber 
termasuk pendidikan formal yang dijalankan oleh responden, pelatihan yang diberikan oleh perusahaan, hingga pengalaman yang dirasakan oleh responden sendiri. Menurut Notoatmodjo (2007), pengetahuan merupakan hasil dari pengindraan manusia atau hasil tahu seseorang terhadap objek melalui indra yang dimilikinya melalui mata, hidung, telinga, dan sebagainya. Pekerja mampu mengidentifikasi adanya bahaya melalui pengindraan tersebut. Oleh karena itu, pekerja dengan pengetahuan yang baik dapat mencegah terjadinya kecelakaan kerja baik pada dirinya maupun orang lain.

Pengetahuan merupakan salah satu faktor manusia terkait penyebab dasar terjadinya kecelakaan kerja. Pengetahuan merupakan landasan seseorang untuk melakukan sebuah tindakan. Selain melalui pendidikan formal, pengetahuan dapat diperoleh melalui cara coba-coba, pengalaman sendiri, maupun pengalaman orang lain. Contoh pengetahuan didapat melalui pengalaman adalah ketika pekerja pernah mengalami kecelakaan akibat memperbaiki mesin yang sedang menyala, maka pekerja tersebut akan belajar bahwa sebaiknya memperbaiki mesin dilakukan dalam keadaan mesin tersebut sedang tidak beroperasi.

Data yang didapat menyatakan bahwa $80,3 \%$ pekerja yang memiliki pengetahuan baik jarang melakukan unsafe action dan sisanya memiliki pengetahuan yang cukup dan kurang. Responden dengan pengetahuan baik banyak yang melakukan unsafe action dengan intensitas yang jarang terjadi karena mayoritas pekerja di Departemen Rolling Mill memang jarang melakukan unsafe action. Sehingga, ketika diteliti banyak pekerja dengan pengetahuan baik yang melakukan unsafe action walaupun dengan intensitas yang rendah. Pengetahuan yang baik harus didukung dengan sikap dan tindakan yang baik agar pengetahuan sejalan dengan sikap dan tindakannya. Meskipun pengetahuan pekerja sudah baik namun terlihat masih banyak pekerja yang melakukan unsafe action, sehingga pekerja masih harus selalu diingatkan untuk tidak melakukan unsafe action ketika bekerja.

Hasil analisis uji statistik yang dilakukan menggunakan korelasi Spearman menunjukkan bahwa terdapat hubungan antara tingkat pengetahuan dengan unsafe action dengan nilai $p$ sebesar 0,028 (nilai $p<0,05$ ) dengan korelasi sebesar $-0,262$. Hubungan tersebut memiliki korelasi negative yang berarti bahwa semakin baik tingkat pengetahuan maka akan semakin berkurang unsafe action yang dilakukan begitu juga sebaliknya. Terdapat kuat hubungan yang cukup antara tingkat pengetahuan dengan unsafe action, maka dari itu perusahaan perlu memperhatikan tingkat pengetahuan pekerja untuk mengurangi tindakan tidak aman yang dapat menyebabkan kecelakaan. Mempertahankan dan meningkatkan pengetahuan pekerja dapat dilakukan dengan memberikan pelatihan dan sosialisasi mengenai keselamatan kerja.

Hal tersebut didukung dengan penelitian Hapsari (2013) yang menyatakan bahwa ada hubungan antara pengetahuan dengan unsafe action. Penelitian lain yang sejalan adalah penelitian yang dilakukan oleh Shiddiq (2013) yang menyatakan bahwa terdapat hubungan antara pengetahuan dengan perilaku tidak aman (unsafe action). Selain itu, hasil yang serupa juga ditemukan pada penelitian Septiana \& Mulyono (2014) yaitu terdapat hubungan yang signifikan antara pengetahuan dengan unsafe action. Sesuai dengan pernyataan Maulidhasari et al. (2011) bahwa setiap perilaku seseorang ditentukan oleh pengetahuan dan perilaku yang didasari oleh pengetahuan akan lebih langgeng daripada perilaku yang tidak didasari oleh pengetahuan.

\section{SIMPULAN}

Kegiatan safety inspection di PT. X telah dilakukan secara rutin dan langkah pelaksanaannya telah sesuai dengan teori. Sebanyak 51,4\% responden menyatakan bahwa penerapan safety inspection di PT. X khususnya di Departemen Rolling Mill telah dilaksanakan dengan baik. Jenis unsafe action yang paling banyak dilakukan oleh responden adalah ketidakrapian dalam penataan barang maupun alat kerja di lingkungan kerja. Jenis unsafe action yang jarang dilakukan adalah berada dalam keadaan mabuk atau mengantuk saat bekerja. Sebagian besar responden memiliki kategori unsafe action rendah atau kadang-kadang. Terdapat hubungan yang bermakna antara safety inspection dengan unsafe action dengan kuat hubungan yang cukup antara keduanya. Selain itu, terdapat hubungan yang bermakna pula antara tingkat pengetahuan dengan unsafe action dengan kuat hubungan yang cukup.

\section{DAFTAR PUSTAKA}

Arikunto, S., 2006. Prosedur Penelitian: Suatu Pendekatan Praktek. Jakarta: Rineka Cipta

Hapsari, Y., 2013. Hubungan Antara Predisposing, Enabling, Dan Reinforcing Factors Dengan Unsafe Action (Studi Di PT. Waskita Karya 
(Persero) Pada Proyek Pengembangan Bandara Internasional Juanda Surabaya), Skripsi. Surabaya: Fakultas Kesehatan Masyarakat Universitas Airlangga

Hughes, P. \& Ferrett, E., 2013. International Health and Safety at Work: For The NEBOSH International General Certificate. 2nd ed. New York: Routledge

Maulidhasari, D. N., Nurjanah, Yuantari, M. C., 2011. Faktor-Faktor yang Berhubungan dengan Perilaku Berbahaya (Unsafe Action) pada Bagian Unit Intake PT. Indonesia Power Unit Bisnis Pengembangan (UBP) Semarang 2011. Jurnal VISIKES, [e-Jurnal] 10(1), pp. 6-17

Notoatmodjo., 2007. Promosi Kesehatan dan Ilmu Perilaku. Jakarta: Rineka Cipta

Oktavianti, I. P., 2014. Hubungan Faktor Internal dengan Unsafe Actions pada Pekerja Konstruksi Proyek Jalan Tol Surabaya-Mojokerto Seksi IV PT. Wijaya Karya (Persero) TBK. Skripsi. Fakultas Kesehatan Masyarakat Universitas Airlangga

Permatasari, F., 2015. Hubungan Faktor Penyebab Dasar dan Manajemen dengan Tindakan Tidak Aman Pekerja Finishing PT. X. Skripsi. Surabaya: Fakultas Kesehatan Masyarakat Universitas Airlangga

Pratama, A. K., 2015. Hubungan Karakteristik Pekreja dengan Unsafe Action pada Tenaga Kerja Bongkar Muat di PT. Terminal Petikemas Surabaya. The Indonesian Journal of Occupational Safety and Health, [e-Jurnal] 4(1): pp. 64-73

Pratomo, A. A. \& Widajati, N., 2013. Tingkat Pemenuhan Safety Inspection Menurut International Safety Rating Systems di Bukit Tua Development Project PT PAL Indonesia Persero Tahun 2013. The Indonesian Journal of Occupational Safety and Health, [e-Jurnal] 2(1): pp. 28-34
Rishadi, T., 2008. Penerapan Safety Inspection di Bagian Paper Machine I PT. Kertas Leces (Persero). Tugas Akhir. Surabaya: Fakultas Vokasi Universitas Airlangga

Safety Sign Indonesia., 2015. Fakta Mengejutkan Teori Domino Heinrich tentang Kecelakaan Kerja. . News, [Online]. Bandung: Safety Sign Indonesia

Septiana, D. A., Mulyono., 2014. Faktor yang Mempengaruhi Unsafe Action pada Pekerja di Bagian Pengantongan Urea. The Indonesian Journal of Occupational Safety and Health, [e-Jurnal] 3(1): pp. 25-34

Stranks, J., 2007. Human Factors and Behavioural. 1st ed. Oxford: Elsevier Ltd

Suardi, R., 2007. Sistem Manajemen Keselamatan dan Kesehatan Kerja: Panduan Penerapan Berdasarkan OHSAS 18001 \& Permenaker 05/1996. Cetakan Kedua ed. Jakarta: Penerbit PPM

Suma'mur., 2009. Higiene Perusahaan dan Kesehatan Kerja (Hiperkes). Jakarta: Sagung Seto

Tarwaka., 2014. Keselamatan dan Kesehatan Kerja: Manajemen Implementasi K3 di Tempat Kerja. 2nd ed. Surakarta: Harapan Press Surakarta

Undang-Undang Republik Indonesia Nomor 13 Tahun 2003 Tentang Ketenagakerjaan. Jakarta: DPR RI

Wicaksono, D.T., 2014. Penyebab Terjadinya Substandar Practice berdasarkan Teori Loss Causation Model pada Pengelas di PT. Bangun Sarana Baja, Skripsi. Surabaya: Fakultas Kesehatan Masyarakat Universitas Airlangga 